\title{
Efficacy of Intravenous Immunoglobulin Therapy in a Patient with Papular Purpuric Gloves and Socks Syndrome due to Parvovirus B19 Infection
}

\author{
Parvovirüs B19 Enfeksiyonuna Sekonder Papüler Purpurik Eldiven ve Çorap \\ Sendromu Gelişen Bir Hastada İntravenöz İmmünglobulin Tedavisinin Etkinliği
}

\author{
Dilara Beşli Çelik'(iD), Aytaç Yaylacı Göktuğ(iD), Deniz Karakaya²(iD), Deniz Tekin²(iD), Esra Çakmak Taşkın(iD),

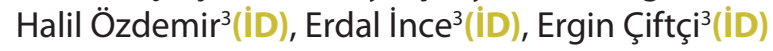 \\ ${ }^{1}$ Department of Pediatrics, Ankara University School of Medicine, Ankara, Turkey \\ ${ }^{2}$ Division of Pediatric Emergency Medicine, Department of Pediatrics, Ankara University School of Medicine, Ankara, Turkey \\ ${ }^{3}$ Division of Pediatric Infectious Diseases, Department of Pediatrics, Ankara University School of Medicine, Ankara, Turkey
}

Cite this article as: Beşli Çelik D, Yaylacı Göktuğ A, Karakaya D, Tekin D, Çakmak Taşkın E, Özdemir H, et al. Efficacy of Intravenous immunoglobulin therapy in a patient with papular purpuric gloves and socks syndrome due to parvovirus B19 infection. J Pediatr Inf 2020;14(3):e141-e144.

\section{Abstract}

Papular-purpuric gloves-and-socks syndrome (PPGSS) is a rare disease characterized by a painful and pruritic symmetric erythematous lesion with a typical localization on the hands and feet, besides mucosal lesions of the oral cavity. Although various viruses such as varicella zoster virus, Epstein-Barr virus, cytomegalovirus, herpesvirus 6/7, Cocksackie virus, hepatitis $B$ virus, and rubella cause PPGSS, the most often reason is parvovirus-B19. Moreover, these lesions are less common in pediatric patients than adults. In this case report, we aimed to present a 13-yearold patient with PPGSS secondary to parvovirus B19 successfully treated with intravenous immunoglobulin therapy.

Keywords: Intravenous immunoglobulin, papular-purpuric gloves-andsocks syndrome, parvovirus B19

\section{Introduction}

Exanthematous diseases of the childhood are frequently seen, and the disease spectrum that should be kept in mind for differential diagnosis is quite extensive. While exanthemas are basic findings of some childhood diseases, they are also
Öz

Papüler purpurik eldiven ve çorap sendromu (PPEÇS), el ve ayaklarda tipik lokalizasyona sahip ağıılı, kaşıntılı ve simetrik eritematöz lezyonların yanı sıra ağız boşluğunun mukozal lezyonları ile karakterize nadir bir hastalıktır. PPEÇS'ye neden olan etiyolojik ajan olarak genellikle parvovirüs B19 saptanmakla birlikte varicella zoster virüs, Epstein-Barr virüs, sitomegalovirüs, herpesvirüs $6 / 7$, Cocksackie virüs, hepatit $B$ virüsü ve kızamıkçık gibi virüslere de rastlanmaktadır. Ayrıca bu lezyonlar pediatrik yaş gruplarında erişkinlere göre daha nadir görülmektedir. Bu olgu sunumunda parvovirüs B19 enfeksiyonuna sekonder PPEÇS gelişen ve intravenöz immünglobulin ile başarılı şekilde tedavi edilen 13 yaşında bir hastayı sunmayı amaçladık.

Anahtar Kelimeler: İntravenöz immünglobulin, papüler purpurik eldiven ve çorap sendromu, parvovirüs B19

minor findings that occur during the course of some diseases (1). These exanthemas may be of maculopapular, petechial, purpuric, vesiculobullous, urticarial or nodular character. Although most childhood exanthematous diseases are self-limiting, some can be the findings of a life-threatening, severe disease $(1,2)$. Just as viral and bacterial infections such as mea-

\section{Correspondence Address / Yazışma Adresi \\ Dilara Beşli Çelik \\ Ankara Üniversitesi Tıp Fakültesi, \\ Çocuk Sağlığı ve Hastalıkları Anabilim Dalı, \\ Ankara-Türkiye \\ E-mail: dilarabesli@gmail.com}


sles, rubella, scarlatina, varicella, erythema infectiosum, roseola infantum, Epstein-Barr virus (EBV), and cytomegalovirus (CMV) can be the underlying reason, exanthema may accompany certain allergic, autoimmune, metabolic, neoplastic diseases, and collagen tissue diseases. Furthermore, drug-related exanthemas should be definitely considered in differential diagnosis (3).

Parvovirus B19, which is the agent of erythema infectiosum (fifth disease), one of childhood exanthematous diseases, is a DNA virus belonging to the Parvoviridae family $(1,4)$. Together with progressing mostly asymptomatic, dermatological findings in a wide spectrum, including reticular erythema, maculopapular exanthema, petechia, and purpura, can be seen in some patients. Recently, parvovirus B19 cases causing papular purpuric exanthema as gloves and socks distribution have been reported (1-5). This study aimed at presenting a 13-year-old patient developing papular purpuric gloves and socks syndrome (PPGSS) secondary to parvovirus B19 infection and recovering successfully with intravenous immunoglobulin (IVIG).

\section{Case Report}

A 13-year-old male patient was brought to the emergency service with complaints including petechial exanthema that had started three days prior and spread to all extremities, fever reaching $38.5^{\circ} \mathrm{C}$, extensive body pain, and sore throat. The patient did not have a chronic disease, drug use or history of previous infection. The patient, who seemed quite weak, was learned to have tremendously decreased oral intake over the past week. Physical examination revealed a body temperature of axillary $38.5^{\circ} \mathrm{C}$, blood pressure $90 / 75 \mathrm{mmHg}$, peak heart rate $140 / \mathrm{min}$, and oxygen saturation was within normal ranges. Patient's oropharynx and conjunctivas were bilaterally hyperemic. The patient had extensive petechial exanthema intensifying distally on the extremities, distinctive sensitivity of the muscles on palpation, and myalgia and arthralgia preventing him from walking (Figure 1). Other system examinations were normal.

Laboratory examinations found hemoglobin $15.5 \mathrm{~g} / \mathrm{dL}$, leucocyte count $4.3 \times 10^{9} / \mathrm{L}$, total neutrophil count $2.9 \times 10^{9} / \mathrm{L}$ and thrombocyte count $63 \times 10^{9} / \mathrm{L}$, activated partial thromboplastin time 31.1 seconds, prothrombin time 12.9 seconds, D-dimer $989 \mathrm{ng} / \mathrm{mL}$, and fibrinogen level $4.62 \mathrm{~g} / \mathrm{L}$. Peripheral blood smear was normal. Biochemical analyses measured sodium as $127 \mathrm{mmol} / \mathrm{L}$, albumin as $2.8 \mathrm{~g} / \mathrm{dL}, \mathrm{C}$-reactive protein as $98 \mathrm{mg} / \mathrm{L}$, and erythrocyte sedimentation rate as $41 \mathrm{~mm} / \mathrm{h}$, and renal and liver function tests were found normal. Complete urinalysis was normal. No growth occurred in throat, blood and urine cultures. No pathological finding was detected on chest X-ray. His exanthemas were seen to spread from the distal towards the proximal of the extremities during clinical follow-up.

Since the family had a history of being engaged in animal husbandry, rickettsia, brucella, and Crimean-Congo Hemorrhagic fever were also suspected but their test results were confirmed negative. Besides, CMV and EBV viral serologies were found negative. Bone marrow aspiration biopsy in terms of hematological malignancies was carried out for the patient who was monitored to have insistent fever, continuing thrombocytopenia, and deepening leucopenia to $1.4 \times 10^{9} / \mathrm{L}$. No finding favoring any malignancy was found. Furthermore, hemophagocytic lymphocytic histiocytosis, which was among our differential diagnoses due to insistent fever, exanthema, bicytopenia, and hypertriglyceridemia, was ruled out since there was no evidence of hepatosplenomegaly, hypofibrinogenemia and decrease in ferritin as well as liver function tests, bilirubin, lactate dehydrogenase and coagulation parameters

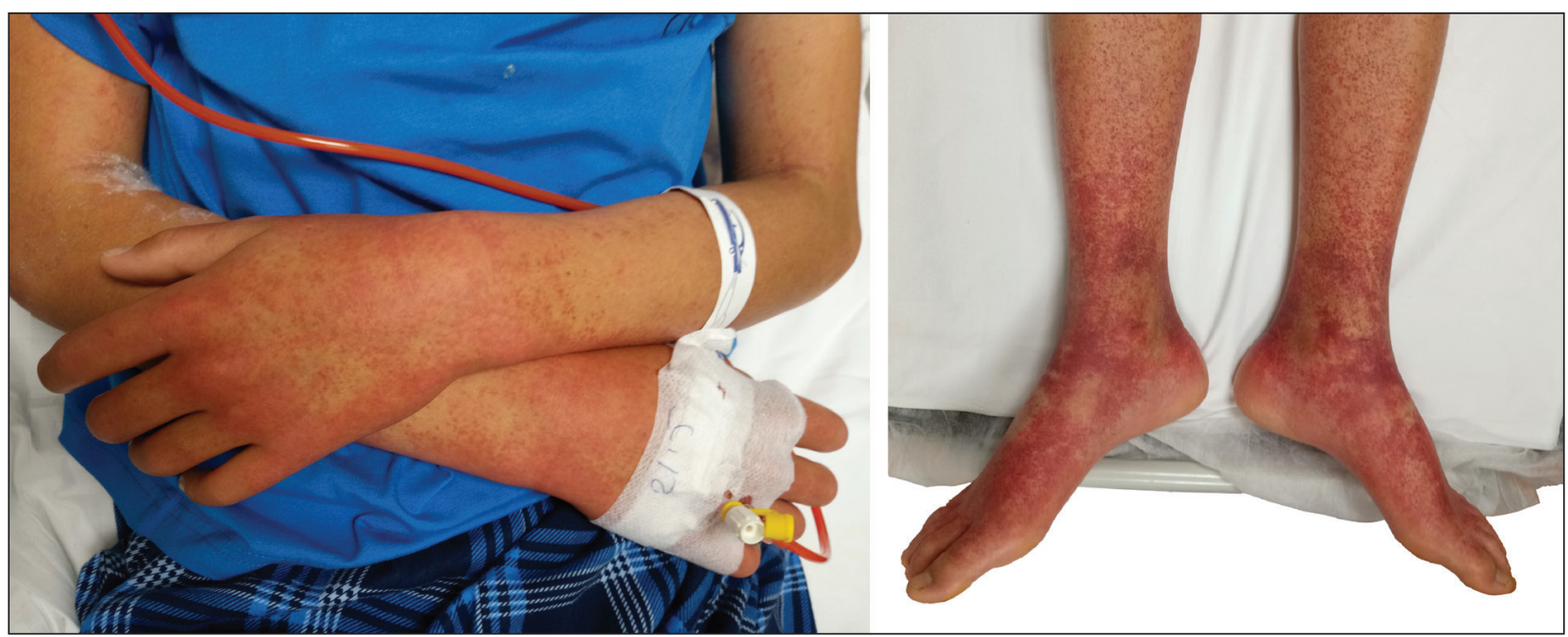

Figure 1. Petechial purpuric gloves and socks exanthemas seen in the distal of hands and feet. 
were detected normal, and no finding compatible with hemophagocytosis was confirmed in bone marrow aspiration biopsy. In tests conducted for vasculitis retraction, ANA and anti-dsDNA resulted negative and C3 was $0.45 \mathrm{~g} / \mathrm{L}(0.98-2.01)$ and $\mathrm{C} 4$ was $<0.01 \mathrm{~g} / \mathrm{L}$ (0.17-0.51). No finding suggestive of vasculitis was detected on the skin biopsy performed on the fourth day of admission. Thus, Henoch-Schönlein purpura considered in the differential diagnosis of purpura was ruled out. Coronary arteries of the patient were evaluated normal in echocardiography performed for incomplete Kawasaki disease in the patient who had insistent fever, exanthema, erythema on hands and feet, and non-exudative bilateral conjunctivitis ongoing for five days.

Within this period, the patient's parvovirus B19 DNA level was resulted as $24.900 \mathrm{IU} / \mathrm{mL}$, and due to the insistent fever reaching $40^{\circ} \mathrm{C}$ and ongoing thrombocytopenia and leucopenia, the patient was suspected having parvovirus-associated gloves and socks syndrome, and hence was started on antipyretic treatment symptomatically and antibiotic treatment consisting of cefepime (150 mg/kg/day) and doxycycline (4/ $\mathrm{mg} / \mathrm{kg} /$ day) for accompanying secondary bacterial infections. Single dose $400 \mathrm{mg} / \mathrm{kg} /$ day IVIG was also administered to the patient whose immunoglobulin levels of $\lg \mathrm{G}, \lg A$ and $\lg M$ had been found respectively as $1100 \mathrm{mg} / \mathrm{dL}$ (907-1958), 139 $\mathrm{mg} / \mathrm{dL}$ (96-465) and $41.5 \mathrm{mg} / \mathrm{dL}$ (83-282) before IVIG. While the exanthemas of the patient started to regress as of day 5 of admission and his bicytopenia tended to ameliorate, the insistent fever dropped on day 7. Cefepime and doxycycline treatments of the patient was stopped when culture results determined negative for rickettsia and brucella. The patient was discharged from the infectious diseases ward on day 10 upon observing betterment in his clinical and laboratory findings. On the follow-up control a week later, the lesions were seen to have improved with desquamation. On the long-term follow-up of the patient ongoing for over a year, bicytopenia did not relapse and the patient remained in good general condition.

Written and oral consent of the patient's family was received for patient information and images used in the study.

\section{Discussion}

Parvovirus B19, which is a small DNA virus, was found by Cossart et al. in the year 1975 (6). It is generally transmitted by respiratory secretions, blood transfusion, organ transplantation, and transplacental route (4). Parvovirus B19, which is the agent of childhood erythema infectiosum, can lead to arthropathies in adults and aplastic crisis in patients with chronic hemolytic anemia. The infection in pregnancy causes hydrops fetalis and congenital anemia in the baby $(1-3,6)$.
Infections associated with parvovirus B19 are generally mild, self-limiting and controlled by the development of specific immune response. However, the clinical condition can be more complex at times, and treatment may be required. Underlying genetical and insufficient immune response are responsible for this condition (7). Prodromal symptoms can generally be symptoms like fever, fatigue, anorexia, arthralgia, myalgia, lymphadenopathy, mucosal lesions, and gastrointestinal symptoms $(4,6,8)$. Disease symptoms in children progress milder when compared to adults $(4,8)$. Laboratory findings include mild leucopenia, temporary thrombocytopenia, elevated liver enzymes, and increase in C-reactive protein levels and rarely in erythrocyte sedimentation rate. Parvovirus B19 can be confirmed by PCR analysis in serum/skin biopsy samples and by serologic analysis $(3,4)$. However, months and even years after recovering from the parvovirus B19 infection, parvovirus B19 DNA positivity can be detected in some immunosuppressed patients. Therefore, in the event of positivity of parvovirus DNA in low titers, a previous parvovirus infection should be definitely kept in mind. Thus, the high level of parvovirus B19 DNA positivity detected in our patient and no history of previous fifth disease or any other infections made us consider primarily that this was associated with an acute parvovirus infection (9).

Harms et al. (10) defined PPGSS for the first time in 1990 reporting five cases with dermatosis characterized with acute, self-limiting and localized erythema that showed spread in a style of gloves and socks starting from distal upper and lower extremities. A short time afterwards, Bagot and Revuz have reported the relation between PPGSS and parvovirus B19 (11). This syndrome, manifesting itself with sharply-circumscribed, rapidly progressive, itchy, and painful erythema and edema starting from the distal of hands and feet, can lead to pharyngeal erythema, edema on lips, painful oral erosions and vulvar edema by showing mucosal involvement. Lesions limit themselves in 7-14 days and resolve with desquamation $(1,3,11)$. Parvovirus B19 virus frequently induces this clinical condition, which is rarely encountered (4-6). Moreover, this condition is also induced by infectious agents such as the varicella zoster virus, Epstein-Barr virus, cytomegalovirus, herpesvirus 6/7, Cocksackie virus, hepatitis B virus, rubella virus and mycoplasma (3). Even drugs like trimethoprim-sulphametaxasole have been reported to cause PPGSS-like reactions $(3,4)$. However, the pathogenesis of the disease is not yet understood $(1,8)$. Furthermore, many symptoms such as insistent fever, exanthema, erythema on hands and feet, and conjunctivitis show similarity with the diagnostic criteria of Kawasaki disease, and thus Kawasaki disease should be kept in mind in differential diagnosis and coronary artery involvement must be ruled out as in our case (12). 
Many patients respond to non-steroidal anti-inflammatory drugs and symptomatic approach with antipyretic treatment, and exanthemas limit themselves within a few days. Additionally, despite limited in numbers, IVIG has been proven to be an efficient treatment in immunosuppressed patients with parvovirus B19-associated red blood cell aplasia and for clinical syndromes related with persistent parvovirus infection in cases with parvovirus B19-associated arthritis, vasculitis, fetal anemia, meningoencephalitis or sporadic chronic fatigue syndrome (13). Although the impact mechanism of IVIG is not fully known, it is considered that the specific anti-B19 immunoglobulins found within IVIG directly bind with the functionally-associated epitopes on the viral capsid and prevent the infectivity of the virus (7).

The patient in our study presented with fever, arthralgia, myalgia, and papular purpuric gloves and socks exanthemas. Acute phase reactants of the patient were moderately increased, and laboratory results showed leucopenia and thrombocytopenia. Parvovirus PCR positivity of the patient was supportive of the PPGSS diagnosis developing secondary to parvovirus B19 infection. Symptomatic treatment and single dose IVIG administered to the patient resulted in improvement in clinical and laboratory findings in ten days.

In conclusion, despite the long-known relation between PPGSS and parvovirus, this syndrome has been rarely defined in children. PPGSS should definitely be in the preliminary diagnosis of cases with distally-localized petechial and purpuric exanthema on the extremities accompanied by fever, arthralgia myalgia, and lymphadenopathy. IVIG can be considered an effective treatment alternative in these patients even without an underlying immune deficiency after having eliminated other exanthematous diseases and hematological disorders in the event of no regression in clinical findings.

Informed Consent: Written and oral consent to record and publish information was received from the patient's family.

Peer-review: Externally peer-reviewed.

Author Contributions: Concept - DBÇ, AYG, DT, EÇ; Design - DBÇ, DK, EÇT, HÖ, EÇ; Supervision - DT, HÖ, El, EÇ; Materials - DT, HÖ, El, EÇ; Data Collection and/or Processing - DBÇ, AYG, DK, EÇT; Analysis and/ or Interpretation - DBÇ, DT, HÖ, El, EÇ; Literature Review - DBÇ, AYG, DK, EÇT; Writing - DBÇ, AYG, DT, EÇ; Critical Review - DBÇ, AYG, DK, DT, EÇT, HÖ, El, EÇ.

Conflict of Interest: No conflict of interest was declared by the authors.

Financial Disclosure: The authors declared that this study has received no financial support.

\section{References}

1. Tuccio A, Zanelli G, Rodriguez DC, Tataranno ML, Vascotto M, Balestri P. Petechial rash associated with Parvovirus $B 19$ in children: case report and literature review. Infez Med 2014;22:250-4. [CrossRef]

2. Aydinöz S, Karademir F, Süleymanoglu S, Ozkaya H, Göçmen I. Parvovirus B19 associated papular-purpuric gloves-and-socks syndrome. Turk J Pediatr 2006;48:351-3. [CrossRef]

3. Kappers W, Stevens $G$, Bruynseels P, van den Akker M. Papular purpuric gloves and socks syndrome because of a Mycoplasma infection. J Pediatr 2018;194:258-e2. [CrossRef]

4. Bello S, Fanizzi R, Bonali C, Serafino L, Terlizzi N, Lapadula G. Papularpurpuric gloves and socks syndrome due to parvovirus B19: a report of two simultaneous cases in cohabitant families. Reumatismo 2013;65:40-5. [CrossRef]

5. Parez N, Dehee A, Michel Y, Veinberg F, Garbarg-Chenon A. Papularpurpuric gloves and socks syndrome associated with B19V infection in a 6-year-old child. J Clin Virol 2009;44:167-9. [CrossRef]

6. Toyoshima MT, Keller LW, Barbosa ML, Durigon EL. Papular-purpuric "gloves and socks" syndrome caused by parvovirus B19 infection in Brazil: a case report. Braz J Infect Dis 2006;10:62-4. [CrossRef]

7. Manaresi E, Gallinella G. Advances in the development of antiviral strategies against parvovirus B19. Viruses 2019;11:E659. [CrossRef]

8. Chinsky JM, Kalyani RR. Fever and petechial rash associated with parvovirus B19infection. Clin Pediatr (Phila) 2006;45:275-80. [CrossRef]

9. Söderlund M, von Essen R, Haapasaari J, Kiistala U, Kiviluoto O, Hedman K. Persistence of parvovirus B19 DNA in synovial membranes of young patients with and without chronic arthropathy. Lancet 1997;349:10635. [CrossRef]

10. Harms M, Feldmann R, Saurat JH. Papular-purpuric "gloves and socks" syndrome. J Am Acad Dermatol 1990;23(5 Pt 1):850-4. [CrossRef]

11. Bagot M, Revuz J. Papular-purpuric "gloves and socks" syndrome: primary infection with parvovirus B19? J Am Acad Dermatol 1991;25(2 Pt 1):341-2. [CrossRef]

12. Agarwal S, Agrawal DK. Kawasaki disease: etiopathogenesis and novel treatment strategies. Expert Rev Clin Immunol 2017;13(3):247-58. [CrossRef]

13. Kerr JR, Cunniffe VS, Kelleher P, Bernstein RM, Bruce IN. Successful intravenous immunoglobulin therapy in 3 cases of parvovirus B19associated chronic fatigue syndrome. Clin Infect Dis 2003;36(9):100-6. [CrossRef] 